Final accepted manuscript ('post-print'). The Version of Record of this manuscript has been published and is available in Globalisation, Societies and Education, March $7^{\text {th }}$ 2021, doi: $\underline{10.1080 / 14767724.2021 .1897946}$

Citation:

Tore Bernt Sorensen, Christian Ydesen \& Susan Lee Robertson (2021). "Re-reading the OECD and education: the emergence of a global governing complex - an introduction." Globalisation, Societies and Education 19(2), 99-107. doi: 10.1080/14767724.2021.1897946

\title{
Re-reading the OECD and education: the emergence of a global governing complex - an introduction
}

Tore Bernt Sorensen ${ }^{\mathrm{a}}$, Christian Ydesen ${ }^{\mathrm{b}}$, and Susan Lee Robertson ${ }^{\mathrm{c}}$

a Institute for the Analysis of Change in Contemporary and Historical Societies (IACS), UCLouvain, Louvainla-Neuve, Belgium

b Department of Culture and Learning, Aalborg University, Denmark

c Faculty of Education, University of Cambridge, United Kingdom

\begin{abstract}
This article introduces the Special Issue 'Re-reading the OECD and education: the emergence of a global governing complex'. Its distinctive contribution is related to its dual epistemological aims: to explore how different conceptual lenses and methodological approaches add to our understanding of the OECD as an intergovernmental organisation; and second, to understand the ways in which the strategic activities and priorities of the OECD have been constructed, historically and contemporarily, and the implications in terms of governance and education on a global scale. Broadly, this dual dynamic - of 'seeing the OECD' and 'seeing like the OECD' - has generated the papers included in this Special Issue. Our Introduction outlines the specific foci and contributions of these papers with reference to four thematic lines of analysis in the research literature: (i) the changing capacities and positions of the OECD in global governance; (ii) the main ideas and styles of reasoning underpinning OECD governance; (iii) the formal and informal processes and workings of OECD's policy formation; and (iv) the impact and wider implications of the OECD in education policy and practice.
\end{abstract}




\section{Re-reading the OECD and education: the emergence of a global governing complex - an introduction}

\section{This Special Issue}

This Special Issue (SI) was borne out of discussions of how to more comprehensively analyse and theorise the Organisation for Economic Co-operation and Development (OECD), its trajectory and diverse roles in contemporary global governance. The title of the SI "Re-reading the OECD and education: the emergence of a global governing complex" was an invitation to leading scholars to engage in new theoretical and empirical readings of the OECD. Taken together the ten papers that make up this SI promise to generate a step-change in the analysis of the OECD as a global governor.

This SI has a dual epistemological aim: first, to explore how different conceptual lenses and methodological approaches add to our understanding of the OECD as an intergovernmental organisation; and second, to understand the ways that the strategic activities and priorities of the OECD have been constructed, historically and contemporarily, and the implications in terms of governance and education on a global scale. It is the dynamic created by these dual aims of 'seeing the OECD' and 'seeing like the OECD' that has generated the papers in this SI.

\section{'Seeing like the OECD': the legibility of education at the global scale}

The 'seeing like the OECD' perspective (Sharman 2012) is an important reference point for us. Elaborating on James Scott's (1998) seminal work on 'seeing like a state', Jason Sharman (2012) observes that research about state-making has tended to focus on the use of violence, force and coercion, rather than the other constitutive - and perhaps even primary - factor in state-craft, that is, bureaucratic administration. Sharman's account of OECD tax policy generates a productive comparison between the ways that bureaucracy, administrative co-ordination and classification are central components for states and international organisations like the OECD in their engagement in governance:

...just as states were created and have been developed ever since through a circular process of intervening in society to make it more legible to facilitate future state interventions, now international organisations act to make global society more legible in order to facilitate future exercises of global governance. The key concept is Scott's legibility: replacing idiosyncratic and particularistic local arrangements with a uniform bureaucratic grid, at first nationally, but now increasingly on a global scale. In this way, central controllers can 'read' and thereby attempt to manipulate society in matters large and small. (Sharman 2012, 18)

The 'seeing like the OECD' perspective suggests a wide-ranging research agenda that might be addressed from a range of different vantage points, in terms of disciplines, conceptual and methodological resources. Importantly, this agenda has been hinted at in the existing literature on the OECD and education. A large body of the work on the OECD sits within and contributes to what we might call a sociology of quantification (Desrosières 2002; Rose 1991) with a focus on the role of indicators and benchmarks (Grek 2009; Sorensen 2016). More recent work has tried to nuance this 
analysis through the concept of ordinalisation (Fourcade 2016) so as to highlight the ideological and affective aspects of commensuration driven by a 'vertical vision' of education governance (Robertson 2019; Sorensen and Robertson 2020).

The re-scaling associated with the emergence of the global education policy field has also been subject to approaches adopting Bourdieu's and Bernstein's theories, both of them originally strongly associated with a methodological nationalist lens on the state's education sectors. Pioneered by Lingard and colleagues from the mid-2000s onwards (see Lingard et al. 2005), Bourdieu has received growing interest from scholars in education and social sciences more generally, applying his theories to the analysis of transnational social fields, symbolic orders and positions over time (Mangez and Hilgers 2012; Ydesen forthcoming). Meanwhile, the conceptual grammar of Bernstein that is more specifically attuned to education sectors has been deployed to analyse the OECD's state-like functions at the transnational scale, evident, for example, in the strategic use of the Programme for International Student Assessment (PISA) and Teaching and Learning International Survey (TALIS) as distinctive pedagogic devices for symbolic control to frame and align identities towards competitive knowledge economies (Robertson and Sorensen 2018). Both offer us original 'rereadings' of the OECD using theoretical resources applied in new ways. These approaches stimulated our interest in a SI centred on the idea of re-reading the OECD and the uneven and continuously contested progress towards 'educational legibility' at the global scale.

As an entry point into our project, we sketch out what we see as the four thematic lines of analysis in the research literature on the OECD so as to introduce the specific foci and knowledge contributions of the papers:

1. The changing positions and capacities of the OECD in the wider and evolving field of global education governance

2. The main ideas, theories and styles of reasoning informing the OECD's legitimacy and governance

3. The formal and informal processes and workings of OECD's policy formation

4. The impact, influence and wider implications of the OECD in education policy and practice

In making sense of the OECD's historical trajectory and formation as a central cog in a "global governing complex" (Ydesen 2019), it is important to note that these four themes are interdependent and co-constitutive. Accordingly, the papers included in the SI tend to address more than one of these themes, though with different emphases.

\section{The changing positions and capacities of the OECD in global governance}

This first theme relates to the broader geo-political developments in global governance in the post-WW II era, where the OECD has carved out a niche for itself while positioning itself vis-à-vis the pressures and demands from member states, other international organisations, and business interests. There is a substantial body of literature on these issues. It is undisputed that the OECD has a pivotal role in contemporary global education governance by coining influential yet rather vague concepts such as "knowledge-based economy" and solidifying those concepts with empirical data, the steady publishing of reports, and a range of programme activities and policy reviews in education 
(Godin 2006; Jakobi and Martens 2010; Wiseman and Taylor 2017). The history of the OECD's changing positions and capacities as a major agent in, and conduit of, the global educational policy field since the 1960s is also relatively well-described (though see Theme 3 below), including the OECD's relations to other major organisations such as UNESCO and the European Commission (Addey 2021; Lawn and Grek 2012).

Currently, the OECD is an important site for institutional networks that have evolved into a 'global political superstructure' (Ougaard 2010). The workings of this superstructure are characterised by soft governance (Niemann and Martens 2018), multilateral surveillance (Martens and Jakobi 2010), and projection or reference (Waldow and Steiner-Khamsi 2019). In education, Sellar and Lingard (2013) argue that 'infrastructural governance' and 'epistemological governance' are key to the OECD's capacity to exert influence and power in member states and beyond. This can be seen as a set of international networks and systems that the OECD has established to collect and compare statistical data, giving the OECD the capacity to shape the views of actors in education across scales. As a result, today the OECD has a key role in encoding what it means to be an effective system, a competent learner, and an excellent teacher.

Nevertheless, it might be argued that the OECD finds itself operating in a difficult environment in the post-financial crisis era. The OECD's current brand of expertise and authority on educational matters is essentially based on the quantification of student learning outcomes conceived as 'cognitive skills', with alleged effects on economic competitiveness and growth, a relatively narrow platform which has been subject to substantial critique (Komatsu and Rappleye 2017; Valiente 2014; Zhao 2020). As a result of mounting criticism about the relevance and validity of PISA, the OECD's most highly profiled programme, there have been signs of 'PISA-fatigue' in several countries (Engel and Rutkowski 2018). Still, the OECD has launched a host of spin-off products associated with the programme, including PISA4U, PISA for Development, PISA for Schools, and PISA for five-yearolds (Lewis 2019).

This SI addresses the ongoing adaptation and potential re-orientation of the OECD in the global education policy field. Two SI papers can be singled out here. Auld and Morris (2021) analyse the OECD's changing roles within the global governing complex revolving around the United Nations (UN)-driven Sustainable Development Goals (SDGs). Inspired by recent scholarship in international relations, their contribution is distinctive in drawing upon narrative theory to highlight the central role of strategic narratives in forging world order and in establishing organisational legitimacy. Tracing the entwined development stories of PISA and the advent of Humanitarian Assessment, they demonstrate shifts in the OECD's strategic narratives aimed at expanding its influence in international development. With regard to the SDGs as a narrative, they show how it constitutes a 'grand' story in symbolic terms, yet also one which is synthetic in the ways that it has drawn together conflicting strands of international development thought, forging a superficial unity of purpose among a diverse range of actors.

The other paper, written by Robertson (2021), sketches out an alternate genealogy of the recently launched PISA Global Competence Assessment. Drawing on Dipesh Chakrabarty's concept (2003), Robertson argues the Global Competences project is a 'provincial' initiative, in the sense that it is an ideational project reflecting a distinctive worldview, as well as a political project pursued by the OECD in collaboration with Asia Society, experts and brokers in élite US universities, and the 
US Department of State for Education. Robertson suggests that its aim is to advance US corporate capital's interests through the cultural production of the new worker citizen able to participate in the global economy, while managing its tendencies to reduce social cohesion. However, since the politics of the Global Competence Assessment are all too visible, buy-in by Member States is poor and the survey results confusing, the project at this point does not appear likely to become influential. This raises the questions: has the OECD's PISA assessment reached its limits? Is the proliferation of PISA products a symptom of an organisation in crisis, or merely that the OECD seeks to make the most of its current position?

Together, these two papers highlight the ongoing challenges for the OECD in adapting to changing circumstances and maintaining its relevance. While the PISA programme has become a consolidated feature of global education governance (see in this SI Komatsu and Rappleye 2021) and the OECD appears to have positioned itself as an indispensable partner for measuring SDG progress (Fontdevila and Grek 2021), the proliferation of policy agents in the field raises the question of who should the OECD strike an alliance with and whom should it compete with? Other pressing developments, including anti-globalist calls for the resurgence of the nation-state, have arguably challenged the very workings and priorities of globalisation, including the modus operandi promoted by the OECD.

\section{The main ideas, theories and styles of reasoning informing the $\mathrm{OECD}$}

This theme emphasises the OECD as an actor (see also in this SI, Centeno 2021) guided by distinctive theories. These sets of ideas largely revolve around development, progress, growth and modernisation and have been fundamental for the organisation's legitimacy as global governor.

Much of the associated research has focused on numbers, statistical indicators, quantification and comparison as policy instruments enabling soft modes of governance, legitimated by an allegedly scientific approach to data gathering (Cussó and D'Amico 2005; Martens 2007). A central argument here is that comparative education research has been colonised by liberal or neoliberal ideology, centred on vertically arranged classifications of student performances, systems, schools and workforces that help to promote a culture of competitiveness infused by ideas of markets, standards and accountability (Nóvoa and Yariv-Mashal 2003; Sorensen and Robertson 2020). This argument goes some way in explaining the OECD's style of reasoning over the years, along with the organisation's embrace of human capital theory and active support of the nascent economics of education discipline in the 1960s (Resnik 2006), as well as the subsequent advocacy of master concepts such as national innovation systems and knowledge-based economy (Godin 2006).

In this SI, Seitzer, Niemann and Martens (2021) add important nuances to this line of argumentation. With a wide-ranging analysis of the OECD's education publications issued between 1961 and 2018, they argue that there is not an overarching institutional architecture for education outputs in the OECD, since various sub-departments in the OECD publish reports on similar topics. Rather than unified and monolithic, the OECD has thus developed a multi-centric view on education, a point which has implications for Theme 3 (see section below).

A slightly different literature drawing on political economy and the history of ideas delves deeper into the paradigms of modernisation, development and growth informing OECD activities. In this perspective, numbers and comparison are also understood as important tools for the OECD since 
its inception, yet they are here associated with distinctive models of development based on the assumption that elite-led industrialisation, a commitment to welfare provision, and technological diffusion would lead the world on its course towards a universal and monolithic modernity. These models were indebted to post-war developments in the US, as the modernisation mandarins charted a course toward the future (Gilman 2003; Tröhler 2014). The OECD did thus not invent these ideas of progress and modernisation, however it has applied, elaborated and redefined them, especially when modernisation theory was heavily critiqued during the 1970s (Schmelzer 2016).

In the SI, Tröhler and Maricic (2021) contribute to this debate with an original and engaging account of the religious roots of the modern conviction to standardised, scientific education policy and its inherent 'sciento-social epistemology', in which notions of faith and salvation are inscribed. They trace the discursive roots of a distinctive idea of social governance and moral order from the Scottish Presbyterians of the 16th century, via early experimental psychologists at Teachers College, Columbia University around 1900, to US education policy in the post-Sputnik cold war crisis and its global diffusion via the "temple of growth" that is the OECD (Schmelzer 2016). In doing so Tröhler and Maricic put the contemporary debate about the explicit future orientation in governance via what some writers call 'anticipatory global governance' (Berten and Kranke 2019), with its own limitations arising from shortfalls in 'promissory legitimacy' (Beckert 2020), into a new and intriguing perspective.

\section{The processes and workings of $\mathrm{OECD}$ policy formation}

From its historical origins as the Organisation for European Economic Cooperation (OEEC), later morphing into the OECD in September 1961, the organisation has formed an arena for nationstates to compare their policies, sharing and diffusing ideas, framed by a human capital perspective (Godin 2006; Resnik 2006). In this respect, the OECD has historically provided an institutional means especially for the US to exert influence internationally (Tröhler 2014).

In line with an emerging research agenda (Bürgi 2017; Centeno 2017; Elfert and Ydesen 2020), this SI contains several papers which examine what takes place in the 'backstage' of the OECD hence going beyond its 'front stage' of formalised structures. By delving into this 'black box', the SI adds important insights about the internal workings as well as the patterned structures and processes which have enabled the OECD to secure its position in contemporary education governance. Three papers in the SI stand out (see also Robertson 2021 in this issue). What they have in common is that they rely extensively on archival sources, including, for example, meeting minutes and other internal OECD documents.

Grek and Ydesen (2021) give a detailed history of the OECD Indicators of Education Systems (INES) programme which paved the way for PISA. Grek and Ydesen argue the INES programme (see also in this SI, Seitzer et al. 2021) was crucial to setting the OECD on a path to becoming a dominant global education policy actor by realising the organisation's ambitions of bringing the education sciences closer with policy-making. Applying a science and technology studies approach focused on education indicators as 'boundary objects', they demonstrate the interdependencies of the scientific and the political in the rise of the OECD in global education governance. Whereas much of the extant research tends to focus on the role of the US due to the implications of the 1983 report $A$ 
Nation at Risk (see Krejsler 2020), this paper also argues France was strongly engaged in supporting the INES programme.

In a rather different contribution to the SI, Hof and Bürgi (2021) unpack the OECD as an arena for debate on computers in schools at the turn of the 1970s. Addressing a remarkable gap in the history of educational technology, they demonstrate how computer education was an integral part of the OECD's policy agenda for curriculum development. Hof and Bürgi highlight the way the OECD Centre for Educational Research and Innovation (CERI) formed an arena for multi-lateral debates and coalition-building about computer education, as well as creating a platform for the OECD to take on the role of actor advocating the introduction of computers in the classroom.

Also focused on the 1970s and the OECD's struggles for survival at the time, the SI contribution by Vera Centeno (2021) explains the OECD's development with reference to three constitutive dimensions of the organisation: as a distinctive actor, multilateral arena, as well as instrument for governments or other policy actors. Adopting an ontological perspective, Centeno discusses in depth the 'pluri-dimensionality' of the OECD, with its overlapping and conflicting institutional, legal, social and political responsibilities.

With their detailed analyses of the workings of the OECD, its organisational structures, partnerships, struggles and antagonisms, the three SI papers above render the 'global' in education governance tangible, along with the agencies involved. Thereby, the papers unpack what is too often represented as a monolithic, homogeneous and univocal organisation (Carroll and Kellow 2011; Valiente 2014; see also in this SI, Seitzer et al. 2021). By gleaning insights into the workings of the OECD bureaucracy and its administrative re-ordering of societies, the papers highlight the state-like role of the OECD and its modernist bureaucracy in the efforts to 'see' national societies so as to render them legible as a single unified entity.

\section{Impact, influence, and wider implications of the OECD in education policy and practice}

A final theme concerns the influence of, and wider implications arising from, the OECD in member states and beyond. This theme also emphasises the outcomes of the three other themes. Three papers in the SI especially address this theme, with different foci on national and regional education reform, perceptions among teachers, and the response of the research community.

Regarding education reform, there is now a comprehensive literature on the influence of the OECD on policy and practice globally. Yet studies also show that the impact of OECD activities varies greatly across localities, and that different meanings are attributed to these activities (Grek 2009; Waldow and Steiner-Khamsi 2019; Wiseman and Taylor 2017). Furthermore, 'seeing like the OECD' means that its activities are increasingly envisaged to be of relevance to agents and institutions around the world, also beyond the OECD member states. The creation of the OECD Centre for Co-operation with Non-Members is one manifestation of the increasing number of countries across all continents now operating under the OECD realm of influence (Martens and Jakobi 2010). The OECD's launch of PISA for Development and the engagement with the UN SDGs (cf. Theme 1 above) also reflect the broadened agenda (Auld et al. 2019), whilst other OECD activities such as PISA for Schools target schools and teachers directly, thereby circumventing governments altogether (Lewis 2019). 
However, studies that trace and theorise the dynamics within and across spatial scales remain rare. In this SI, two papers, one by Moreno-Salto and Robertson (2021) and the other by Takayama and Lingard (2021), provide detailed accounts of reforms in Mexico and Japan, respectively, and the ways they are entangled with the OECD. Drawing on a multi-scalar dataset on the Mexican education system, Moreno-Salto and Robertson highlight the contingent 'life of PISA numbers' - from teachers in schools who barely know about PISA data, to politicians who use PISA to legitimate political purposes, and policymakers who draw upon much earlier renditions of PISA so that it now enters into Mexican education policy and practices through a metaphoric back door. Their set of different vantage points enable them to empirically demonstrate the very different understandings and uses of PISA numbers that potentially undermine educational objectives. Takayama and Lingard's paper also emphasises the contingent nature of contemporary reform, as they trace the complexities and tensions involved in the creation of a 'scientific' assessment in a Prefecture in Japan. Drawing on interviews with policy actors and a distinctive Actor Network Theory approach which is sensitive to structural constrains and power relations (see also in this SI, Grek and Ydesen 2021), their thick description documents the assemblage of discursive, material and technical elements coming together in the creation of the assessment policy, including inspiration from PISA and networks with high profile figures such as Andreas Schleicher, Director of the OECD Education and Skills Directorate.

Finally, the OECD's epistemological governance (Sellar and Lingard 2013) has had major implications for education research communities worldwide. In this respect, a critical literature has discussed the excessive focus on statistics, indicators and International Large-Scale Assessments (ILSAs) as the primary forms of ' evidence' for policy-making (Grek 2009; Nóvoa and Yariv-Mashal 2003). In this SI, Komatsu and Rappleye (2021) provide a critique of PISA that is generative for theory and practice in order to move beyond the existing standoffs of 'for' or 'against' PISA in educational research. Their entry point is that PISA and similar ILSAs will remain an enduring and powerful feature of the global educational landscape. In four instructive steps, Komatsu and Rappleye develop distinctive research strategies for rearticulating ILSAs such as PISA through the meaningful and creative use of data, thereby shifting the exercise away from dissemination of one dominant and culturally saturated worldview of 'good' education towards the recognition of alternatives.

\section{Concluding remarks}

Each of the ten papers in this SI contribute to our understanding of the multiple ways in which 'seeing like the OECD' translates into rendering the world legible in educational terms, as well as the complex political, economic, social and educational challenges confronting the OECD in the associated administrative re-ordering and unification of societies. In this respect, the papers approach or 'see' the OECD differently as a research object. Together, they demonstrate the epistemological gains to be had by drawing on new disciplinary-based and theoretically innovative readings of, and angles on, the historical trajectory of the OECD. With their theory-laden and detailed analysis sensitive to the complex, poly-centric and multi-directional dynamics of the global education policy field, the papers suggest ways to transcend the binary of methodological nationalism and methodological globalism that has long dominated the research literature about the OECD. Many questions remain, and more will emerge, yet we hope this SI will be widely read and debated for its 
contribution to new understandings of the OECD - in theoretical and epistemological terms - and the roles the organisation plays in the emergence of a global governing complex in education.

\section{References}

Addey, C. 2021. "Passports to the Global South, UN Flags, Favourite Experts: Understanding the Interplay between UNESCO and the OECD within the SDG4 Context." Globalisation, Societies and Education. Advance online publication. doi:10.1080/14767724.2020.1862643

Auld, E., and P. Morris. 2021. "A NeverEnding story: Tracing the OECD's Evolving Narratives within a Global Development Complex." Globalisation, Societies and Education. Advance online publication. doi:10.1080/14767724.2021.1882959

Auld, E., J. Rappleye, and P. Morris. 2019. "PISA for Development: How the OECD and World Bank Shaped Educational Governance Post-2015." Comparative Education 55 (2): 197219, doi:10.1080/03050068.2018.1538635

Beckert, J. 2020. "The Exhausted Futures of Neoliberalism: From Promissory Legitimacy to Social Anomy." Journal of Cultural Economy 13 (3): 318-330, doi:10.1080/17530350.2019.1574867

Berten, J., and M. Kranke. 2019. "Studying Anticipatory Practices of International Organizations: A Framework for Analysis." Paper presented at $6^{\text {th }}$ European Workshop in International Studies, Krakow, June 26-29.

Bürgi, R. 2017. "Engineering the Free World: The Emergence of the OECD as an Actor in Education Policy, 1957-1972." In The OECD and the International Political Economy Since 1948, edited by M. Leimgruber and M. Schmelzer, 285-309. Cham: Springer International Publishing.

Carroll, P. G. H., and A. J. Kellow. 2011. The OECD: A Study of Organisational Adaptation. Cheltenham, UK: Edward Elgar.

Centeno, V. G. 2017. The OECD's Educational Agendas: Framed from Above, Fed from Below, Determined in an Interaction: A Study on the Recurrent Education Agenda. Frankfurt am Main: Peter Lang.

Centeno, V. G. 2021. "The OECD: Actor, Arena, Instrument." Globalisation, Societies and Education. Advance online publication. doi: 10.1080/14767724.2021.1882958

Chakrabarty, D. 2003. Provincializing Europe: Postcolonial Thought and Historical Difference. Princeton: Princeton University Press.

Cussó, R., and S. D'Amico. 2005. "From Development Comparatism to Globalization Comparativism: Towards more Normative International Education Statistics." Comparative Education 41 (2): 199-216.

Desrosières, A. 2002. The Politics of Large Numbers: A History of Statistical Reasoning. Cambridge, MA: Harvard University.

Elfert, M., and C. Ydesen. 2020. "The Rise of Global Governance in Education: The OEEC and UNESCO, 1945-1960." In Organizing the World: International Organization and the Emergence of International Public Administration 1920-1960, edited by K. Gram-Skjoldager, H. A. Ikonomou, and T. Kahlert, 73-89. London: Bloomsbury.

Engel, L. C., and D. Rutkowski. 2018. "Pay to Play: What Does PISA Participation Cost in the US?" Discourse: Studies in the Cultural Politics of Education 41 (3): 484-496. doi: $\underline{10.1080 / 01596306.2018 .1503591}$ 
Fontdevila, C. and S. Grek. 2021. "The construction of SDG4: Reconciling democratic imperatives and technocratic expertise in the making of global education data?" In World Yearbook in Education 2021: Accountability and Datafication, edited by S. Grek, C. Maroy and A. Verger, 43-58. New York: Routledge.

Fourcade, M. 2016. "Ordinalization: Lewis A. Coser Memorial Award for Theoretical Agenda Setting 2014." Sociological Theory 34 (3): 175-195. doi:10.1177/0735275116665876

Gilman, N. 2003. Mandarins of the Future: Modernization Theory in Cold War America. Baltimore and London: Johns Hopkins Press.

Godin, B. 2006. “The Knowledge-Based Economy: Conceptual Framework or Buzzword?” Journal of Technology Transfer 31 (1): 17-30.

Grek, S. 2009. “Governing by Numbers: The PISA 'Effect' in Europe.” Journal of Education Policy 24 (1): 23-37.

Grek, S., and C. Ydesen. 2021. "Where Science Met Policy: Governing by Indicators and the OECD's INES Programme." Globalisation, Societies and Education. Advance online publication. doi: $10.1080 / 14767724.2021 .1892477$

Hof, B., and R. Bürgi. 2021. "The OECD as an Arena for Debate on the Future Uses of Computers in Schools." Globalisation, Societies and Education. Advance online publication. doi:10.1080/14767724.2021.1878015

Komatsu, H., and J. Rappleye. 2017. “A New Global Policy Regime Founded on Invalid Statistics? Hanushek, Woessmann, PISA, and Economic Growth." Comparative Education 53 (2): 166191.

Komatsu, H., and J. Rappleye. 2021. "Rearticulating PISA." Globalisation, Societies and Education. Advance online publication. doi:10.1080/14767724.2021.1878014

Krejsler, J. B. 2020. "Imagining School as Standards-driven and Students as Career-ready! A Comparative Genealogy of US Federal and European Transnational Turns in Education Policy." In Handbook of Education Policy Studies: School/University, Curriculum, and Assessment, Volume 2, edited by G. Fan and T. S. Popkewitz, 351-383. Singapore: Springer.

Lawn, M., and S. Grek. 2012. Europeanizing Education: Governing a New Policy Space. Oxford: Symposium.

Lewis, S. 2019. "Historicizing New Spaces and Relations of the OECD's Global Educational Governance: PISA for Schools and PISA4U." In The OECD's Historical Rise in Education: The Formation of a Global Governing Complex, edited by C. Ydesen, 269-289. New York: Palgrave Macmillan.

Lingard, B., S. Rawolle, and S. Taylor. 2005. "Globalizing Policy Sociology in Education: Working with Bourdieu." Journal of Education Policy 20 (6): 759-777. doi.org/10.1080/02680930500238945

Mangez, E., and M. Hilgers. 2012. "The Field of Knowledge and the Policy Field in Education: PISA and the Production of Knowledge for Policy." European Educational Research Journal 11 (2): 189-205. https://doi.org/10.2304/eerj.2012.11.2.189

Martens, K. 2007. "How to Become an Influential Actor: The 'Comparative Turn' in OECD Education Policy." In Transformations of the State and Global Governance, edited by K. Martens, A. Rusconi, and K. Lutz, 40-56. London: Routledge. 
Martens, K., and A. P. Jakobi, eds. 2010. Mechanisms of OECD Governance: International Incentives for National Policy Making? Oxford: Oxford University Press.

Moreno-Salto, I., and S. L. Robertson. 2021. "On the 'life of numbers' in governing Mexico's education system: a multi-scalar account of the OECD's PISA.” Globalisation, Societies and Education. Advance online publication. doi:10.1080/14767724.2021.1880882

Niemann, D., and K. Martens. 2018. "Soft governance by hard fact? The OECD as a knowledge broker in education policy." Global Social Policy 18 (3): 267-283. https://doi.org/10.1177/1468018118794076

Nóvoa, A., and T. Yariv-Mashal. 2003. "Comparative Research in Education: A Mode of Governance or a Historical Journey?" Comparative Education 39 (4): 423-438. doi: $\underline{10.1080 / 0305006032000162002}$

Ougaard, M. 2010. "The OECD's Global Role: Agenda-setting and Policy Diffusion.” In Mechanisms of OECD Governance: International Incentives for National Policy-Making, edited by K. Martens and A. P. Jakobi, 26-49. Oxford: Oxford University Press.

Resnik, J. 2006. "International Organizations, the "Education-Economic Growth" Black Box, and the Development of World Education Culture." Comparative Education Review 50 (2): 173 195. doi.org/10.1086/500692

Robertson, S.L. 2019. "V-Charged: Powering Up the World-Class University as a Global Actor." Paper presented at the European Consortium for Political Research Conference, Wroclaw, September 4-7.

Robertson, S. L. 2021. "Provincializing the OECD-PISA Global Competences Project." Globalisation, Societies and Education. Advance online publication. doi:10.1080/14767724.2021.1887725

Robertson, S. L., and T. B. Sorensen. 2018. "Global Transformations of the State, Governance and Teachers' Labour: Putting Bernstein's Conceptual Grammar to Work." European Educational Research Journal 17 (4): 470-488. doi:10.1177/1474904117724573

Rose, N. 1991. "Governing by numbers: Figuring out democracy." Accounting, Organizations and Society 16 (7): 673-692. doi:10.1016/0361-3682(91)90019-B

Schmelzer, M. 2016. The Hegemony of Growth: The OECD and the Making of the Economic Growth Paradigm. Cambridge: Cambridge University Press.

Scott, J. C. 1998. Seeing Like a State: How Certain Schemes to Improve the Human Condition Have Failed. New Haven: Yale University Press.

Seitzer, H., D. Niemann, and K. Martens. 2021. "Placing PISA in Perspective: The OECD's Multicentric View on Education." Globalisation, Societies and Education. Advance online publication. doi:10.1080/14767724.2021.1878017

Sellar, S., and B. Lingard. 2013. "The OECD and global governance in education." Journal of Education Policy 28 (5): 710-725. doi:10.1080/02680939.2013.779791

Sharman, J. C. 2012. "Seeing Like the OECD on Tax." New Political Economy 17 (1): 17-33. doi: $10.1080 / 13563467.2011 .569022$

Sorensen, T. B. 2016. "Teachers and the Global Educational Policy Field". In The Global Educational Policy Environment in the Fourth Industrial Revolution, edited by T. D. Jules, 5984. Bingley: Emerald. 
Sorensen, T. B., and S. L. Robertson. 2020. "Ordinalization and the OECD's governance of teachers." Comparative Education Review 64 (1): 21-45. doi: https://doi.org/10.1086/706758

Takayama, K., and B. Lingard. 2021. "How to Achieve a 'Revolution': Assembling the Subnational, National and Global in the Formation of a New, 'Scientific' Assessment in Japan." Globalisation, Societies and Education. Advance online publication. doi:10.1080/14767724.2021.1878016

Tröhler, D. 2014. "Change Management in the Governance of Schooling: The Rise of Experts, Planners and Statistics in the Early OECD." Teachers College Record 116 (9): 1-26.

Tröhler, D., and V. Maricic. 2021. "Data, Trust and Faith: The Unheeded Religious Roots of Modern Education Policy." Globalisation, Societies and Education. Advance online publication. doi:10.1080/14767724.2021.1872371

Valiente, O. 2014. "The OECD Skills Strategy and the Education Agenda for Development." International Journal of Educational Development, no. 39: 40-48. doi.org/10.1016/j.ijedudev.2014.08.008

Waldow, F., and G. Steiner-Khamsi, eds. 2019. Understanding PISA's attractiveness: critical analyses in comparative policy studies. London: Bloomsbury Academic.

Wiseman, A. W., and C. S. Taylor, eds. 2017. The Impact of the OECD on Education Worldwide. Bingley: Emerald.

Ydesen, C., ed. 2019. The OECD's Historical Rise in Education: The Formation of a Global Governing Complex. New York: Palgrave Macmillan.

Ydesen, C. Forthcoming. "Crafting Globalization: A Bourdieusian Historical Approach to Studying International Organizations and Global Governance in Education." In Societal Change and Transforming Fields: Pierre Bourdieu in Studies of Organization, edited by S. Robinson, J. Ernst, O. J. Thomasson, and K. Larsen. London: Routledge.

Zhao, Y. 2020. "Two Decades of Havoc: A Synthesis of Criticism against PISA." Journal of Educational Change 21 (2): 245-266. https://10.1007/s10833-019-09367-x 